\title{
Intermédialités
}

Histoire et théorie des arts, des lettres et des techniques

Intermediality

History and Theory of the Arts, Literature and Technologies

\section{Thinking Intermediality in Mexico through Artistic Input}

\section{Susana González Aktories et María Andrea Giovine Yáñez}

Numéro 30-31, automne 2017, printemps 2018

cartographier (l'intermédialité)

mapping (intermediality)

URI : https://id.erudit.org/iderudit/1049951ar

DOI : https://doi.org/10.7202/1049951ar

Aller au sommaire du numéro

Éditeur(s)

Revue intermédialités (Presses de l’Université de Montréal)

ISSN

1920-3136 (numérique)

Découvrir la revue

Citer cet article

González Aktories, S. \& Giovine Yáñez, M. A. (2017). Thinking Intermediality in Mexico through Artistic Input. Intermédialités / Intermediality, (30-31).

https://doi.org/10.7202/1049951ar
Résumé de l'article

Cet article présente quelques moments paradigmatiques de l'art mexicain contemporain de la seconde moitié du $20^{\mathrm{e}}$ siècle jusqu'à aujourd'hui. Il a pour but de montrer l'indéniable " virage intermédial » qui s'est opéré au cours de cette période et qui permet de comprendre certains mouvements artistiques mexicains actuels ainsi que la réflexion qui s'est parallèlement élaborée dans le milieu universitaire. Ce n'est que depuis très récemment que les chercheurs reconnaissent qu'une approche intermédiale peut contribuer à la compréhension et à l'analyse de propositions artistiques qui ne peuvent plus uniquement être discutées d'un point de vue monodisciplinaire. Les contributions des artistes emblématiques Mathias Goeritz, Felipe Ehrenberg et Ulises Carrión, qui ont employé des mots, des images et des éléments sonores pour élargir les frontières artistiques, ont par exemple trouvé un écho chez des artistes visuels comme Carlos Amorales et Jorge Méndez Blake, ainsi que chez des artistes pratiquant les arts médiatiques comme Rafael Lozano Hemmer et Eugenio Tisselli. Ces artistes, puisqu'ils adoptent une posture théorique par rapport à leur pratique, constituent des interlocuteurs pertinents à l'égard de la réflexion sur l’intermédialité. 


\title{
Thinking Intermediality in Mexico through Artistic Input
}

\author{
SUSANA GONZÁlEZ AKTORIES \\ María Andrea Giovine YáñeZ
}

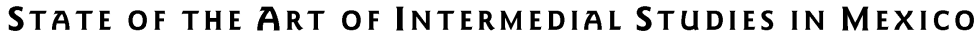

ew lines of disciplinary demarcation, developed during the last decades of the twentieth century through practices such as those proposed by intermediality, have become increasingly accepted within the international academic sphere, including in countries like Mexico. Recent articles and $\mathrm{PhD}$ programs in different disciplines such as comparative literature, musicology, and art history ${ }^{\mathrm{I}}$ have

\footnotetext{
I The National Autonomous University of Mexico (UNAM), as well as the National Autonomous University of the State of Morelos (UAEM), and more recently the Universidad Iberoamericana are some of the few Mexican institutions that have devoted congresses, publications, lectures, seminars, and courses with invited specialists to intermedial studies in the humanities. The Postgraduate Department of Literature, for example, has been one of the precursors, offering since 2010 seminars on intermediality attended by students from different departments (the seminar was led jointly by Irene Artigas Albarelli and Susana González Aktories). Later, the Music Department continued organizing seminars with guest lecturers such as Antonio Baldassarre. Other scholars linked to the UNAM who have focused on intermediality are philosopher and anthropologist Néstor Gacía Canclini and literary theoretician and semiotician Angélica Tornero. Gradually, new generations of graduates have continued offering courses, publishing articles, and presenting research projects with a focus on intermediality - not only as a result of these first efforts, but also as a need to approach more contemporary artistic phenomena from an intermedial perspective; some of them are: María Andrea Giovine, Poesia perceptual: experiencias poéticas interactivas que generan nuevos modus legendi [Perceptual Poetry: Poetic Interactive Experiences That Generate New Modus Legendi], doctoral dissertation, UNAM, Mexico City, 20I2; El trazo de la palabra. La poética de la poesia visual como metavanguardia [The Drawing of Words. The Poetics of Visual Poetry as a Meta-Avant-Garde], master's thesis (Comparative Literature), UNAM, Mexico City, 2005; María Andrea Giovine (ed.), Ver para leer: miradas múltiples a las poéticas visuales, Mexico City, CONACULTA, 20I5; Cinthya García Leyva, De la página del texto al espacio del sonido. Borramientos en el conceptualismo poético a la luz de las materialidades literarias [From the Page of the Text to the Space of the Sound. Erasures in Poetic Conceptualism through the Light of Literary Materialities], master's thesis (Comparative Literature), UNAM, Mexico
} 
demonstrated an interest in and the need for intermedial approaches, following the paths opened by theorists such as Claus Clüver, W. J. T. Mitchell, Werner Wolf, Jens Schröter, Irina Rajewsky, and Jürgen Müller. It is, however, noteworthy that Mexican academia has developed in this direction at a much slower pace compared to the various intermedial proposals and reflections offered by Mexican artists on the creative scene. Intermedial studies in Mexico were initially considered non-specialized and were ignored for having a too broad and therefore vague theoretical and methodological background. In Mexico, intermediality in the early I970s and $1980 \mathrm{os}$ appeared to be a matter of a small group of experimental artists; as a notion, it became partly known through the contact some of them had established with fellow creators such as Dick Higgins, whose texts were translated into Spanish. ${ }^{2}$ Intermediality was therefore considered a way in which creators could explain or justify their artistic processes involving different elements/media that interact with each other (in an either open or veiled manner), rather than a critical perspective that could offer clear sets of tools for literary analyses and art studies.

However, if we take a closer look at the poetics that inspired certain Mexican artists to create their work, particularly those directly interested in questioning the semiotic relations that join language, image, and sound in one object, a different story unfolds: one that allows us to acknowledge the referential development these intermedial practices have had over the past half-century in the Mexican context, and

City, 2016, http://132.248.9.195/ptd2016/marzo/098003747/Index.html (accessed 24 February 2018); Roberto Cruz Arzabal, "Poéticas materiales y edición independiente", Tierra Adentro, 2016, http://www.tierraadentro.cultura.gob.mx/poeticas-materiales-yedicion-independiente/ (accessed 2 March 2017). The importance and application of intermediality to literary studies by graduate students has also been highlighted in publications such as Susana González Aktories and Irene Artigas Albarelli (eds.), Entre artes entre actos. Ecfrasis e intermedialidad [Between Arts, Between Acts. Ekphrasis and Intermediality], Mexico, Bonilla Editores/UNAM, Colección "Pública, 2oIr. Another reference is the article by Susana Gónzalez Aktories, "Intermedialidad e iconotextualidad como coordenadas para el estudio de las materialidades literarias [Intermediality and Iconotextuality as Coordinates for the Study of Literary Materialities],” in María Garone y María Andrea Giovine (eds.), Bibliología e iconotextualidad. Estudios interdisciplinarios sobre la relación entre textos e imágenes, Mexico, IIB/UNAM, in press. In this text, González Aktories takes a look at the concepts of iconotextuality and intermediality and their fundamental importance for understanding materiality in literature.

${ }^{2}$ Dick Higgins, “Algunos conceptos sobre poesía Intermedia,” transl. from Portuguese by César Espinosa, Memoria documental, catalogue of the II ${ }^{a}$ Bienal Internacional de Poesía Visual y Alternativa en México, ${ }^{\text {er }}$ Festival de Poesía Viva México, Departamento del Distrito Federal, 1987, p. 24-26. 
one that offers enriching perspectives for the theoretical understanding of intermediality. In fact, literary research in Mexico in the past few years seems to have been enriched by the aesthetic and conceptual proposals of artists who have deliberately moved into an interartistic realm and who consciously discuss materiality, inscription, and language as conditions for the development of new types of legibility and literacy, conveying a better understanding of intermedial strategies that encompass different forms of communication and that continue to overlap and expand. Today, intermediality is well-established as a useful conceptual tool for working with hybrid objects and as part of that strand of literary studies that approach textuality from a more dynamic and encompassing point of view. ${ }^{3}$

In this article we sketch, rather than exhaustively map, the field in which Mexican artists and artistic movements have, since the second half of the twentieth century, deliberately involved an intermedial perspective with insightful conceptual and theoretical bases, particularly with regard to the relation between language, visual art, and sound art. We have chosen a few representative examples to clarify our points.

\section{Pioneering Artistic Practices and the Beginning of THEORETICAL DISCUSSIONS REGARDING INTERMEDIALITY IN MEXICO}

One of the cardinal points from which we can begin the scenario that we would like to draw here is to consider the decisive role that German sculptor and architect Mathias Goeritz (1915-1990) had in Mexico after immigrating to this country in the mid-I940s. He not only enriched the Mexican cultural scene during the 1950 and 1960 s by reinforcing the exchange between Mexican and European artists-for instance, through the organization of the first exhibition of International Concrete Poetry in 1966 or by creating new conditions and spaces for the exhibition of modern art, such as the museum El Eco ${ }^{4}$ - but also through his role as an artist where he developed his own projects with an intermedial approach, mainly inspired

\footnotetext{
3 For a useful source in understanding intermediality from a semiotic point of view, see Azunción López-Varela Azcárate, "Génesis semiótica de la intermedialidad [Semiotic Genesis of Intermediality]," Cuadernos de Información y Comunicación, vol. I6, Madrid, Complutense University, 20II.

4 This museum, ran by the UNAM, is well known for its emphasis on intermedial practices. Some of the pivotal work done and produced there can be consulted at www.eleco.unam.mx/.
} 
by concretism. As part of the international movement of concrete poetry, he experimented with the expressive possibilities of typographic design in relation to space, such as in Oro [Gold] (1965), a poem based on the repetition of this short but effective palindrome with which he created square patterns in twelve combinatory variations where the cue element was the distance between the letters printed on the page.

Goeritz' poems contributed to introduce concretisms in the Mexican cultural sphere, similarly to Swiss poet Eugen Gomringer's Silencio [Silence](1954) and to poems by the group of Brazilian concrete poets such as Décio Pignatari's Beba Coca Cola [Drink Coca-Cola] (1957). It does not seem coincidental that such apparently simple poems - if judged at first sight from a visual and lexical standpoint-have nevertheless generated multiple analyses focused on their intermedial value. ${ }^{6}$

5 For more details on the relationship between Goeritz and concretism and the origins of visual poetics in Mexico, see Cinthya García Leyva, "El concretismo en México: dos ejemplos de Mathias Goeritz [Concretism in Mexico: Two Examples by Mathias Goeritz]," in María Andrea Giovine (ed.), Ver para leer, Mexico City, CONACULTA, 20I5, p. 213-223; Cinthya García Leyva, "Hacia la verbivocovisualidad. Notas sobre un paideuma posible desde el concretismo en poesía mexicana [Towards Verbivocovisuality. Notes on a Possible Paideuma from Concretism in Mexican Poetry]," in María Garone y María Andrea Giovine (ed.), Bibliología e iconotextualidad. Estudios interdisciplinarios sobre la relación entre textos e imágenes, Mexico City, IIB/UNAM, in press.

${ }^{6}$ The interest in studying visual and concrete poetry as an intermedial practice is present in diverse works by the pioneers of intermedial literary studies such as Claus Clüver in his articles "Reflections on Verbicovisual Ideograms," Poetics Today, Poetics of the Avant-Garde, vol. 3, no. 3, Summer 1982, p. 137-146 and "Concrete Sound Poetry: Between Poetry and Music," in Erik Hedling and Ulla-Britta Lagerroth (eds.), Cultural Functions of Intermedial Exploration, Amsterdam, Rodopi, 2002, p. 163-178. Also, Marjorie Perloff has shown great interest in these matters, for instance in her article "'Concrete Prose' in the Nineties: Haroldo de Campos's 'Galaxies' and after," Contemporary Literature, vol. 42, no. 2, Summer 20oI, Special Issue: American Poetry of the 1990s, p. 270-293. Clüver and Perloff have also contributed to Susana Haydu's valuable section on concrete poetry in the issue CiberLetras: Revista de Critica Literaria y de Cultura / Journal of Literary Criticism and Culture, vol. 17, 2007, https://dialnet.unirioja.es/ejemplar/160659 (accessed 30 November 2017). Even scholars from other disciplines such as architecture and fine arts have devoted interesting approaches to these practices, as is the case of Jennifer Josten in her essay "Mathias Goeritz y la Poesía concreta internacional [Mathias Goeritz and the International Concrete Poetry]," in Tobias Ostrander(ed.), Abstracción temporal/Temporal abstraction, Mexico City, Museo Experimental El Eco, UNAM, 20II. Some of the literary analyses including concrete poetry developed by Mexican scholars with a focus on intermediality are: Cinthya García Leyva, Lo visual, lo verbal y lo sonoro. Aproximaciones al concretismo en poesia mexicana [The Visual, the Verbal and the Sound. Approximations to Concretism in Mexican Poetry], doctoral dissertation, UNAM, 20I2, http://I32.248.9.195/ptd20I2/junio/0680834/Index.html (accessed 
However, in his poetic work, Goeritz distinguished himself from these artists by exploring the visual and spatial potential of this type of writing even beyond the two-dimensional page. As an architect, he aimed to work with text on other surfaces such as walls, creating huge mural-type inscriptions that were to be read on the street: this is the case of the emblematic work Pocos cocodrilos locos [Few Crazy Crocodiles $^{7}$ ](1967), where a meter-wide text was carefully designed in big letters, conveying a monochromatic but still legible texture relief through the shadows created by natural light. At the same time, Goeritz chose a word composition that, in this case, was more than unconventionally playing with the visual legibility of a text when it becomes part of the architecture-as he did in Oro-with the text's sounding effects-here with a sort of tongue-twister. This text was located on the wall of a building that was destroyed by an earthquake in 1985 , so all that is left of this work is the photographic register. ${ }^{8}$

One of Mexico City's most important contemporary museums, the Museo Universitario de Arte Contemporáneo (MUAC), organized a critical review of Pocos cocodrilos locos and of the work produced by many other artists of Goeritz' generation through the very successful exhibition Defying Stability. Artistic Processes in Mexico 1952-1967 (2014). Pocos cocodrilos locos also appeared as a partial reproduction in Critical Constellations of the Audio Machine in Mexico, curated by Carlos Prieto for the Kunstraum Kreuzberg/Bethanien in Berlin (2017). In both exhibitions this poem was reconstructed on a fake wall. Intermedial and interartistic practices were a major concern for the curators of both exhibitions. In the first one, a curatorial section was devoted to what they called Borramientos [Erasures], described in the following terms:

Borramientos traza los caminos de una actividad creativa fundada en el desvanecimiento de los límites entre las disciplinas artísticas. Puede hablarse de una emergencia de las vanguardias contemporáneas internacionales de los

24 February 2018); Giovine, 2005, 20I2; and Irene Artigas Albarelli and Susana González Aktories, "Poesía concreta traducciones entre palabra y sonido", in Nair María Anaya Ferreira (ed.), Leer, Traducir, Reescribir, Mexico, CONACULTA / Bonilla Artigas Editores, 20I4, p. I57-I83.

7 The pun in Spanish is lost in the translation into English.

${ }^{8}$ The visual impression of this poem, even after its disappearance after the 1985 earthquake, much later inspired sound artist Manuel Rocha (1963) to create a sound poem with the same name Pocos cocodrilos locos (1998). To listen to this poem and to see an image of the wall featuring the text, consult https://youtu.be/lhDb-nsUAow (accessed 25 February 2018). 
años cincuenta y sesenta en un ambiente sin un fuerte antecedente de afiliación a los movimientos modernos. ${ }^{9}$

This particular exhibit meant a very important recognition of mid-century neoavant-garde cultural practices in Mexico, in which intermedial and interartistic explorations were shown and analyzed. The catalogue Defying Stability. Artistic Processes in Mexico $1952-1967^{10}$ features critical essays that have become referential for the understanding of these artistic practices and their transcendence in time.

Text and architecture achieved an entirely different effect in one of Goeritz' previous works, Poema plástico [Plastic Poem](1952), a mural that became part of the aesthetic concept of the abovementioned El Eco museum, this time integrating another chromatic element (the contrast between the text in black written on a yellow wall, which served as the background). But here Goertiz was more interested in developing a different aspect of inscription, namely one that creates the impression of hand writing, and thereby visually conveying an emotional effect, very much in tune with his theoretical conceptualization of what he called "emotional architecture,"II which was reinforced because this time the text was illegible, written in a simulated alphabet that just very recently has been decoded. The immediateness of the impression was what counted here. And, despite the illegible alphabet used by Goeritz, viewers of the work could "read" its structure and understand that it is a poem due to the location of the signs.

In the late 1960s the versatile and socially engaged artist and editor Felipe Ehrenberg (1943-2017), who had been a disciple of Goeritz but moved to England for a six-year auto-exile after the violent ending of the student movement of 1968 , became

9 "Erasures outlines the roads of a creative activity well founded in the fading of the limits between artistic disciplines. It is possible to speak of an emergence of the international contemporary avant-gardes in the 1950 and the 1960s in an environment without a strong antecedent of affiliation to modern movements." The translation is ours. More information on this exhibition can be found at http://muac.unam.mx/expo-detalle-9-desafio-a-laestabilidad (accessed 24 February 2018).

Io Rita Eder, Pilar García, and Cristóbal A. Jàcome (eds.), Defying Stability. Artistic Processes in Mexico 1952-1967, exhibition catalogue, March 27-August 3, 2014, Mexico City, INBA/Museo Nacional de Arte.

II In 1953, Goeritz wrote the "Manifesto of Emotional Architecture," where he states that architecture-also understood by Goeritz as an intermedial phenomenon-must have a deep emphasis on the emotions of the people who experience it and in that sense, he theorized that it has deep poetic value, http://eleco.unam.mx/eleco/manifiesto-de-la-arquitecturaemocional-I953/ (accessed I2 June 2017). 
another relevant figure who boosted intermedial ideas and practices in Mexico-and with impact on an international level. Decisive for this was the creation of a collective, independent press, which he founded in Devon in 1970-7I together with Martha Hellion $^{12}$ and Davis Mayor and with the collaboration of other artists and critics. Beau Gest Press/Libro Acción Libre, as it was named, began editing mainly artists' books, starting with its first publication, the FLUXshoe (197I) catalogue, ${ }^{13}$ conceived by Ehrenberg together with Stuart Reid and Barry McCallion as a Fluxus bookexhibition touring through the United Kingdom. The prologue, written by Ehrenberg under the pseudonym Kyosan Bajin, recalled the origins of this international group created in the 1960 and explained that "it exists as a name yet is not a movement; it exists as an organizational framework, yet has no manifesto; it could be taken that it exists as a group, yet the term has been sporadically adopted and used by many other individuals living in far-off places (far from New York, of course)." ${ }^{2}$ Ehrenberg also participated in mail art, one of the main artistic practices that became common during that period and that spread in the 1970s and 1980 among Mexican experimental and visual poets and artists. This artistic international movement was shown in the first mail art exhibition and catalogue presented by Mauricio Marcín (20II), where he had collected some of the mail items created by Mathias Goeritz, Felipe Ehrenberg, Ulises Carrión, Maris Bustamante, César Espinosa, Clemente Padín, Mónica Mayer, Magali Lara, etc. In the abovementioned FLUXshoe prologue Ehrenberg was concerned not only with the diversity of materials and forms of inscription that had already preoccupied artists of Goeritz'

${ }^{12}$ It is important not to forget the role played by female artists of this generation such as Martha Hellion, Magali Lara, Mónica Mayer, and Maris Bustamante. Revisiting their work in the context of intermedial art is still to be done. Helen Escobedo, for example, has played a decisive role in the discussion and constitution of Mexican contemporary art since the r97os. As an artist and as a curator, she has been a key figure directing the Museo Universitario de Ciencias y Artes (Universitary Museum of Sciences and Arts), a university museum considered one of the most important art institutions of the last decades of the twentieth century.

${ }^{13}$ Felipe Ehrenberg [pseudonym Kyosan Bajin], "Prologue," FLUXshoe, Devon, UK, Beau Gest Press/Libro Acción Libre, 197I. Another important text that can be consulted for understanding Ehrenberg's relationship with print media experimentation and his ideas on textuality is the catalogue Radical/Basic/Actual. sg7os Experiments in Print Media: Felipe Ehrenberg, Latin American Artists and the Beau Geste Press (Devon, 1970-1976), exhibition, Io October-I4 November 2016, Centre of Latin American Studies, Cambridge, UK.

${ }_{14}$ "FLUXSHOE: Felipe Ehrenberg, Stuart Reid and Barry McCallion," artcornwall.org, http://www.artcornwall.org/interview_fluxshoe_stuart\%2oreid_felipe_ehrenberg2.htm (accessed II March 2018). 
generation, ${ }^{\text {is }}$ but also with the means of circulation that these unique artistic forms adopted.

As someone interested in the editorial process, Ehrenberg not only encouraged Fluxus proposals, as in the modest but influential magazine Schmuck that was distributed through mail for four years (1972 to 1976) releasing eight issues, ${ }^{16}$ but also different types of visual poetry and neo-Dadaist works, always insisting on the publication of "limited editions, mimeomultiples, concept booklets and pamphlets, magazines" created by “a community of duplicators, printers, and artisans. Our press is not a business, it's a way of life. Beau Geste Press.” ${ }^{17}$ As such, "Beau Geste Press was undoubtedly one of the most productive and influential publishing ventures of its generation.” ${ }^{18}$ (see Fig. I)

It was through these channels that reflections on intermediality, such as those written by Dick Higgins, ${ }^{19}$ also became known. Later, Higgins' texts were not only translated and reproduced in Mexico, but he was also invited as a key participant in the bi-annual festivals Bienales Internacionales de Poesia Visual y Experimental (1985-2009) organized by poet César Espinosa and his fellow artists. ${ }^{20}$ (see Fig. 2 and 3).

\footnotetext{
is Even if we have centred the discussion here on examples of the work and ideas of just a few artists, it is worth mentioning that many more were working on the boundaries of words, images, sound and exploring with intermedial practices. This is the case of the No-grupo in which participated Maris Bustamante, Melquiades Herrera, Alfredo Núñez, and Rubén Valencia. Other groups of artists that used to work with intermedial practices in the ro7os and I980s were Tepito Arte Acá, Proceso Pentágono, Mira, Suma, Germinal, Taller de Arte e Ideología, Taller de Investigación Plástica and Fotógrafos Independientes.

${ }^{16}$ The editorial of the first edition, written by David Mayor, determines that "Schmuck wants the real meat and no fancy dressing. I have no specific ideology to push and would like to see $S c h m u c k$ develop, if not as an open forum for discussion of some of the problems relating to art, at least as a vehicle for artists to present their ideas as well as their art (when the two don't overlap!)," cited in Bean Geste Press, gallery guide, 2 February-28 May 2017, p. 24, http://www.capc-bordeaux.fr/sites/capc-bordeaux.fr/files/bgp_expo_eng.pdf (accessed I2 June 2017).

${ }^{17}$ Reproduction of a handwritten text originally in capital letters, which appeared in the edition of the gallery guide of the Beau Gest Press exhibition in Bordeaux, Ibid., p. 6.

${ }^{18}$ Ibid.

19 Dick Higgins, Intermedia, New York, Something Else Press, 1966; later in Dick Higgins, Horizons. The Poetics and Theory of the Intermedia, Carbonale, Illinois, Southern Illinois University Press, 1984.

${ }^{20}$ We strongly recommend the book edited by Samuel Gordon, La poesia visual en México [Visual Poetry in Mexico], Estado de México, UAEM, 2oII. In this beautiful illustrated edition, the reader can find a series of chapters dedicated to visual poetry in Mexico, including a
} 
But back to Ehrenberg. Besides his engagement in editorial projects, as an artist, he was highly influenced by conceptual and experimental art, exploring graphic design, painting, photography, collage, sculpture, and installations, but also creating book objects, such as the Codex Aeroscriptus Ebrerbergensis (1990) (see Fig. 4), as well as performance and sound poetry. Maneje con precaución [Drive with Caution] (1973) is probably his only known "sound poem," also defined by him as the longest visual poem by ekphrasis. This piece was recorded during a car ride on Calzada Ignacio Zaragoza, one of Mexico City's most active and popular downtown avenues, where he sees all sorts of posters and signs on the street that he attempts to read as if reading the urban landscape through description while speaking with the window open, thus allowing for the murmuring soundscape of traffic to become part of the recording and of the piece itself. ${ }^{21}$

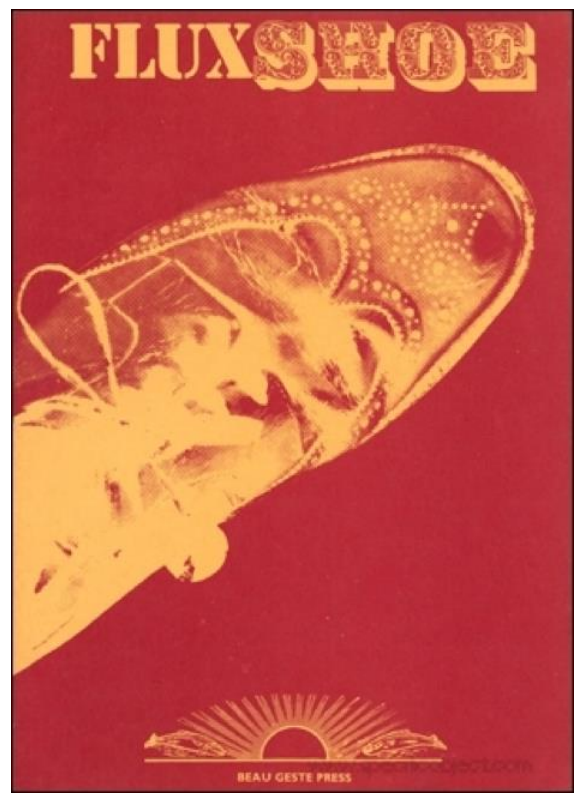

Fig. I. Felipe Ehrenberg, cover of FLUXshoe, 1971, 29 x 21 cm., Devon: Beau Geste Press, I44 pp., unsigned and unnumbered. (C) Lourdes Hernández Fuentes.

historiographic section as well as many theoretical discussions and literary analyses of specific works.

2I "El poema más largo del mundo" and "Naturaleza quieta," can be seen on YouTube as examples of Ehrenberg's work, at https://www.youtube.com/watch?v=sBatPstj2n8 and https://www.youtube.com/watch?v=mfFQ4Dy8upc (accessed I2 June 2017). 

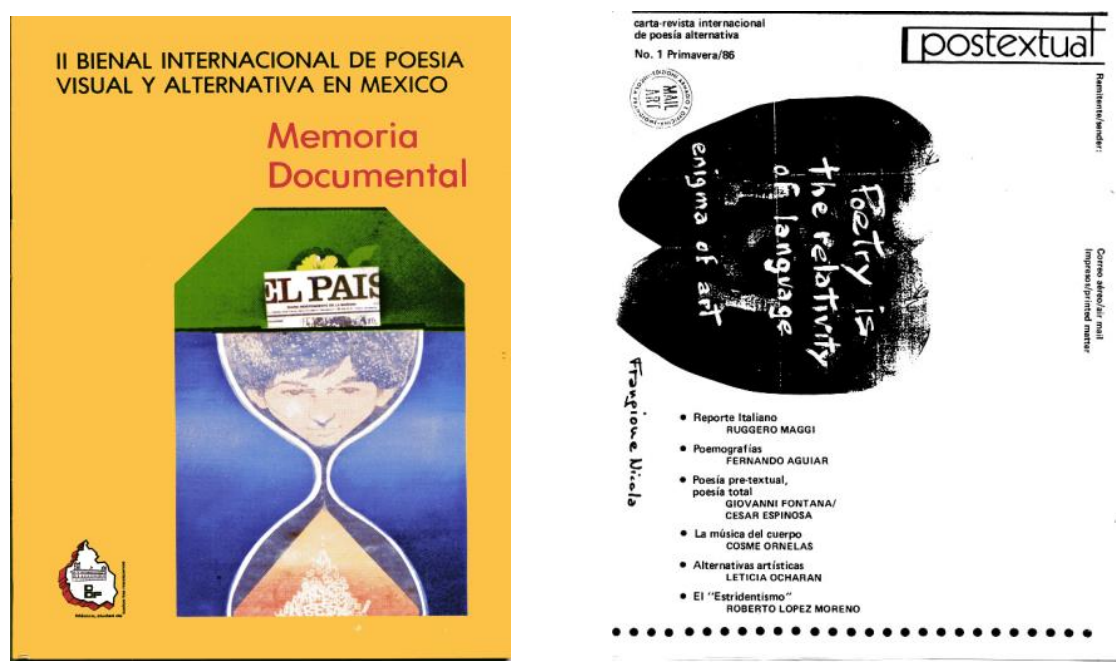

Fig. 2. Cover of the catalogue of the II International Biennial of Visual and Experimental Poetry, October 1987, México City: Departamento del Distrito Federal 56 pp. () César Espinosa.

Ulises Carrión (1941-1989), also an auto-exiled artist living in the Netherlands for reasons that have to do mainly with his art proposals not being understood in Mexico at the time, is another key figure in the constellation of intermedial artists whose work has lately been rediscovered, republished, and revalued by both his peers and by scholars for his ideas on popular art, but most importantly for his explorations on the death of the book, the borders between the book as an object and the object book. El arte nuevo de hacer libros [The New Art of Making Books] gathers a series of essays, some of which he published in Mexican magazines such as Plural in the early 1970s, and which in 2012 were reedited by Juan J. Agius and Heriberto Yépez. ${ }^{22}$

${ }^{22}$ Both Agius and Yépez are experts in Carrión's work, one as art and literary critic and the other as literary essayist; together, they started that same year a program they called "Archivo Ulises Carrión," which was conceived as a series of publications in different volumes by the publishers of La Tumbona. So far, they have published three volumes: Ulises Carrión, El arte nuevo de hacer libros [2012], Mexico City, La Tumbona, 2016; El arte correo y el Gran Monstruo, Mexico City, La Tumbona, 2013; and Ulises Carrión, Lidia Prado Superestrella y otros chismes, Mexico City, La Tumbona, 2014 and 2015. 


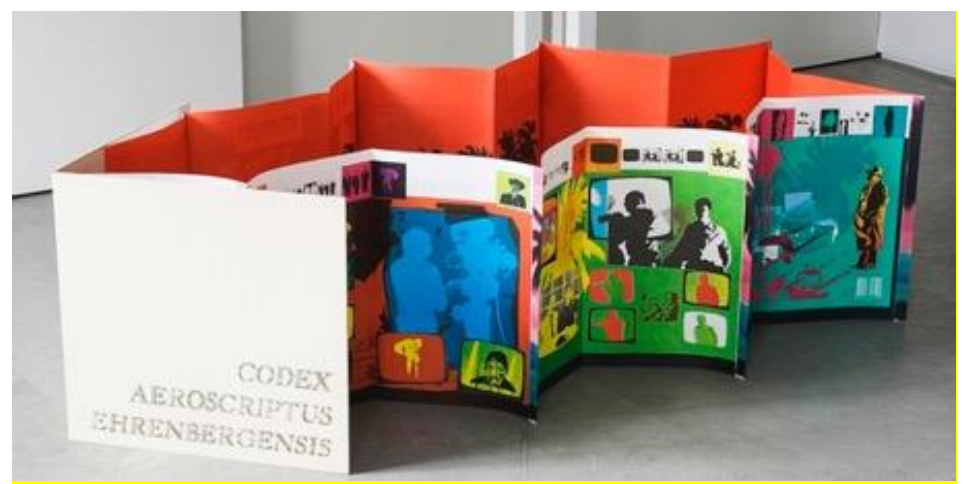

Fig. 4. Felipe Ehrenberg, Codex Aeroscriptus Ehrenbergensis, 1990, Atlanta, Nexus Press. (C) Lourdes Hernández Fuentes.

Like Ehrenberg, Carrión was one of the initiators of the mail art movement that spread in Mexico in the I970s, but in contrast to Ehrenberg, he felt the need to engage in a different form of circulation of artistic discourse, and created in 1975 a bookshop-gallery-archive named Other Books and So, which became an important meeting point for artists at the heart of Amsterdam in the 1970s. As part of the concept "and so," despite the conventional "books," Carrión meant to create:

a space of exhibition and distribution of/ other books/ non books/ anti books/ pseudo books/ quasi books concrete books/ conceptual books/ structural books/ project books/ plain books multiples/ posters/ postcards/ records/ cassettes $^{23}$

As can be derived from this playful and ironic wink, the categorization of material editions became an important topic in Carrión's own creative work, where he actually questioned the ways of reading books and the role played by the book as a sort of interface, for the understanding of its message and content. In fact, one of his most memorable slogans was: "Dear reader. Don't read." ${ }^{24}$

Carrión and Ehrenberg, who met while they were both living in Europe, initiated a rich correspondence that ended in a strong friendship and interesting

23 This text was published as an advertising postcard by the same bookshop.

${ }^{24}$ In 2016, an exhibition entitled, precisely, Dear reader. Don't read was organized at the Reina Sofía Museum in Madrid to show Carrión's influence in the European artistic circuit in the late 1970s. The same exhibition was also shown in Mexico City's Jumex Museum in the first half of 2017, Ulises Carrion. Dear reader. Don't read, 8 February-30 April. 
collaborations as in the case of the publication Looking at Poetry/Tras la poesia (1973), ${ }^{25}$ a bilingual edition that Carrión launched with Ehrenberg's support in Beau Gest Press. This booklet invited the reader to interpret conceptually the eight parallel lines that were printed on the bottom of each page under a title that proposed their "reading" from different perspectives: either as "lines," "whips," "wires," "noodles," "boundaries," or finally "poetry."

In his variations on classical poems, where he used to suppress elements or even entire texts in a Broodthaersian sense, Carrión gestured to a poem's identity simply by its visual form, its silhouette, its structure, according to its mise en page, in a similar way to Goeritz' Poema plástico [Plastic Poem](1953). Carrión, like Ehrenberg, questioned and thereby illuminated the act of reading not only in printed and visual explorations, but also in other material dimensions, for instance, in oral performances registered on a homemade recorded cassette called The Poet's Tongue (1977), ${ }^{26}$ issued in a limited edition (270 copies) by Guy Schraenen and carrying the same title as W. H. Auden's anthology of English verse published in 1935 . Here he presents a series of different readings showing usually unperceived and unvalued structures, as in Hamlet for Two Voices where the text consists only of the alternating reading out, by two voices, of all the character's names in Shakespeare's Hamlet. Carrion hereby seems to propose that a play script is legible not only by its parliament but by the sequence of names of the characters involved in each scene, that is, by a part of the drama which for obvious reasons is omitted in the oral representation. Signification may accordingly be derived not only from the content of this Shakespearean play, but also from its structure, in this case revealing a suggesting rhythmic pattern derived from the simple and mechanical alternation of these enunciated names.

It is worth mentioning that since Carrión's work was reedited and readopted by a new generation of writers and artists in Mexico in the past ten years, there has been a boom in what Roberto Cruz Arzabal has called "material poetics." ${ }^{27}$ Some writers and poets who had not previously explored alternative materialities or the multiple and very diverse creative possibilities of combining image, text, and sound and exploring intermedial zones have started producing works in this direction.

\footnotetext{
${ }^{25}$ Ulises Carrión, Tras la poesia /Looking for Poetry, Devon, UK, Beau Geste Press, 1973.

${ }^{26}$ Ulises Carrión, The Poet's Tongue, recorded cassette, Anvers, Guy Schraenen Éditeur,

27 Arzabal, 2016.
} 1977. 
Carrión not only opened a huge window for intersections between different artistic languages and started a circuit of international creative exchange, but he developed a new poetic of the act of reading as well as a novel idea, at least within the Mexican cultural sphere, of what a book is (a structure, such as language itself) and of the place of materiality and intermediality on the artistic scene and in cultural studies.

Artists such as Goeritz, Ehrenberg, and Carrión established the possibilities of avant-garde art that defined and influenced the next generation of Mexican artists and "exposed" the audiences to a certain kind of proposals based on intersecting discourses, a mixing of media, and social and political engagement. In Mexico City, intermedial practices have been promoted in places such as El Eco Museum, El Chopo Museum, Ex Teresa Arte Actual, and more recently the MUAC and the Jumex Museum. Such practices have systematically been taking place since the 1970s and I980 thanks to the important impulses given by, among other figures, the pioneer artists discussed here.

\section{The New Generation: Continuing And Evolving INTERMEDIAL PRACTICES IN MEXICO}

Turning now to the artists of the newer generation, we can mention the work of Carlos Amorales (born in 1970), ${ }^{28}$ which often deals with the possibility or impossibility of communication through alternative forms of codification-very much in the "tradition" or conceptual line of Goeritz-by creating a semiotic system of invented but plausible signs presented in different media, exploring not only graphic design, painting, and performance, but also including animation and sound through video and film work. Often, this has led him to question the actual means and reaches of translation as well as media.

One of Amorales' most recent exhibitions in which the topic of language and translation became evident was Gravedad [Gravity](2016), presented at the cultural centre Casa del Lago Juan José Arreola. Here the artist entirely exchanged the texts of all written and printed media - including trash cans, posters, announcements, and even web pages - with an apocryphal written text based on an invented alphabet, which may evoke Goeritz' written walls, particularly Poema plástico. ${ }^{29}$ But Amorales

${ }^{28}$ Images of his work can be seen on the site of the Gallery Kurimanzutto, http://www.kurimanzutto.com/artists/carlos-amorales (accessed 24 February 2018).

${ }^{29}$ Another female artist who reinterpreted and theorized Goeritz's Poema plástico from an intermedial perspective was Mexican visual artist, writer, and editor Verónica Gerber Bicecci 
goes far beyond one single space and intention, encompassing all written and verbal communication and information. Confusion, curiosity, frustration, and estrangement are the results of the visitor's confrontation with this discrete and at the same time significant change, which transforms an institution and its structure in a sort of dystopia. A part of this piece included the audience's reaction to this "state of lack of communication": often people got mad and started complaining, completely exasperated by this confusing and disorienting illegibility. This was precisely the artist's intention, to show how, in the middle of an illegible context, we become aware of our constant and natural urban exposure to textuality and how reading texts in a certain institutional space-time-framed context conveys a specific meaning to other more metaphorical acts of legibility such as the perception or "reading" of a space, a form, a structure, a sound, and even a whole set of movements and implicit behaviours under certain conditions.

Inspired by the experience of Gravedad, Amorales created for the Venice Pavilion the installation La vida en los pliegues [Life in the Folds] (2017) (see Fig. 5 and 6), a title that makes reference to a novel by Henri Michaux published in $1949 .{ }^{30}$ In this piece, Amorales continues exploring aspects such as language, writing, and the many different ways of codifying or encrypting it to the point of making it illegible, accessory. In this work, however, he goes one step further by transforming typographical codes into sound codes while creating abstract ceramic wind instruments and flutes in different shapes, each one having a different form and sound according to each letter of that invented alphabet.

Amorales' work is deeply rooted in intermedial reflections and, as the abovementioned artists of the previous generation, he has opened a window for intermedial aesthetic experiences in which the topics of inscription-codification and legibility-illegibility are explored. He has thereby contributed to include Mexico as part of an international scene of artistic work that questions materiality, signification (semiotics), and communication by intelligently and intentionally exploring ideas that draw from conceptualism, concretism, and intermedial practices.

(born in 198I) in her Poema invertido [Inverted Poem] (2013), which includes acrylic painting. She tried to decode the previous poem by flipping it over its own negative. The project was much broader, since she included her notes around the creative process together with a reproduction of her visual poem in a small publication. http://www.veronicagerberbicecci.net/ (accessed 24 February 2018).

${ }^{30}$ Henri Michaud, La vie dans les plis [1949], Paris, Gallimard, 1990. 


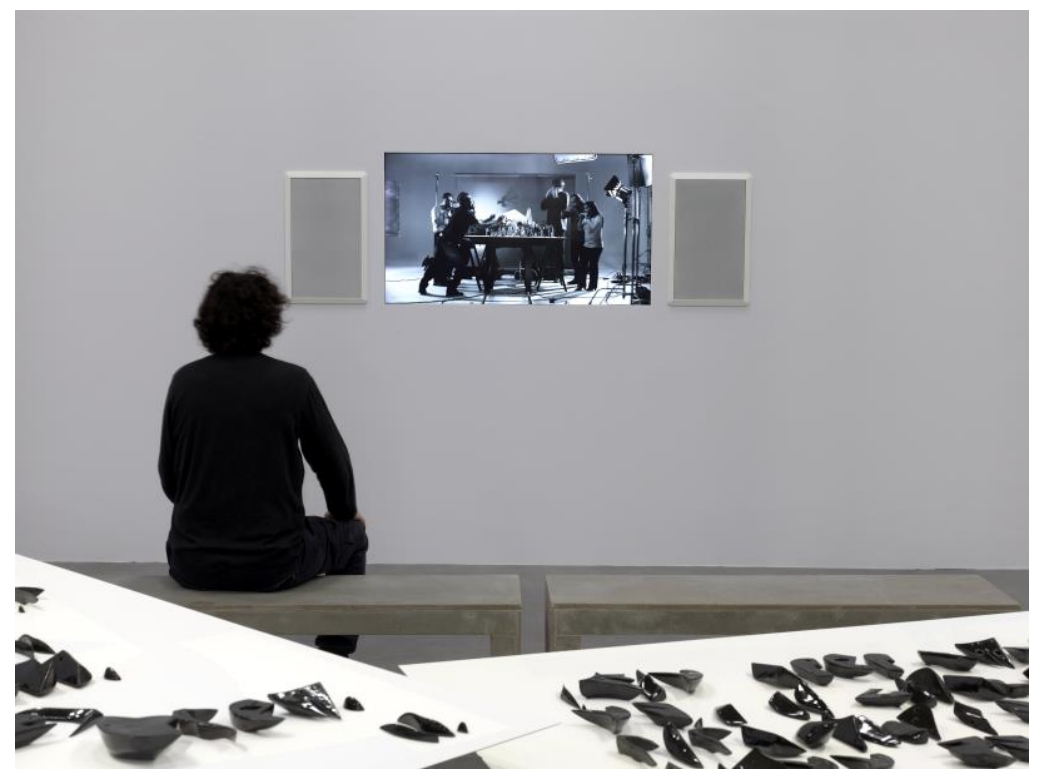

Fig. 5-6. Carlos Amorales, La vida en los pliegues [Life in the Folds], 2017, series of 92 photocopies on metal, 7 folding tables with metal bases and silkscreened Alucobond panels, 924 ceramic ocarinas; I video, $\mathrm{I}_{3}$ ', edition I/5. Installation created by the artist for the Mexican Pavilion at the 57 th Venice Biennale.Colección Instituto Nacional de Bellas Artes y Literatura (INBA) Image courtesy of kurimanzutto and Estudio Amorales. Photo by Dario Lasagni. Reproduced with the kind permission of Carlos Amorales.

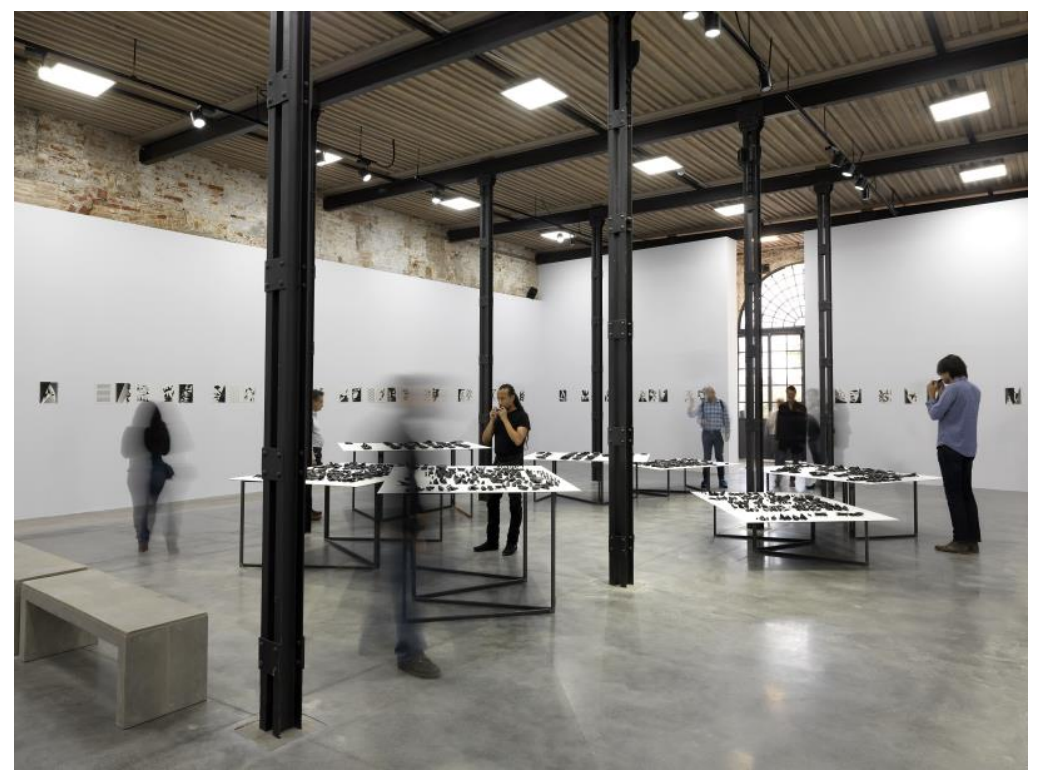

INTERMÉDIALITÉS • $\mathrm{N}^{\mathrm{OS}}$ 3O-3I AUTOMNE 2017 - PRINTEMPS 2018 
Another Mexican visual artist, who studied architecture but then turned to visual arts by approaching intermedial discourses, is Jorge Méndez Blake (born in 1974). ${ }^{3 \mathrm{I}} \mathrm{His}$ work is the result of a constant personal-intertextual—dialogue with the texts of such writers as Emily Dickinson, Jorge Luis Borges, George Perec, and Jules Verne, among many others. Through his plastic work, Méndez Blake invites us to become active readers, not only in the functional means of a basic literacy as in Amorales' case, but rather in the sense of exploring the formal and contextual meanings of a literary work that has been submitted to a process of remediation or intersemiotic translation in order to be presented in a new medium.

Conscious, as Amorales, of the importance of space and context as part of the signifying process, some of Méndez Blake's proposals consist in working with fragments of texts recontextualized through their presence in an exhibition space-a museum or a gallery. One example is his Selected Poems (2014), an installation made with white neon light (an obvious homage to the work of Art \& Language artists such as Joseph Kosuth or Bruce Nauman): it shows the words that give the piece's title over a gray wall, which was part of an exhibit called Al margen del texto [At the Margin of the Text] organized the same year. The title of this exhibit clearly reveals his idea of taking literature and textuality as a departing point for his production as a visual artist. Another piece worth mentioning from this same exhibit is Indices [Table of Contents] (2014), where through the use of an appropiationist approach he presents his new creations, his new poems, derived from an intertextual-intermedial metareference in which he recombines the titles of Federico García Lorca's works. An important detail here is that he proceeded in the form of a traditionally printed poem, on a facsimile-like sheet of paper, as if he were exhibiting a page from a book, thereby making a statement that questions the forms of circulation and transposition of texts in regard to their material support (device-interface) and context (see Fig. 7).

Contributions made by emblematic artists such as Ulises Carrión and Felipe Ehrenberg, who used words, images, and sound elements to broaden the artistic boundaries in new and surprising ways, are in a sense echoed, honoured, and counterpointed by contemporary artists such as Eugenio Tisselli and Rafael Lozano Hemmer, who go one step further by using other kinds of medial and technological interactions. Both have provoked the art scene with works situated at the border of an enriched intermedial stage. Intermedial art in Mexico seems to be thereby also constantly reshaping and reaffirming itself. This is perhaps its most genuine attribute,

${ }^{31}$ His work can be seen at www.mendezblake.com/ (accessed 24 February 2018). 
and we can understand it better if we dare to have a closer look at what has happened mainly since the 1990 os when both young artists have been experimenting with technology and digital language, each in their own way. Sound, image, text, and all their possible relationships and conjunctions became more complex when adding the component of virtuality, interfaces, and the decoding that we as users have to face at the moment of interacting with technology-based art.

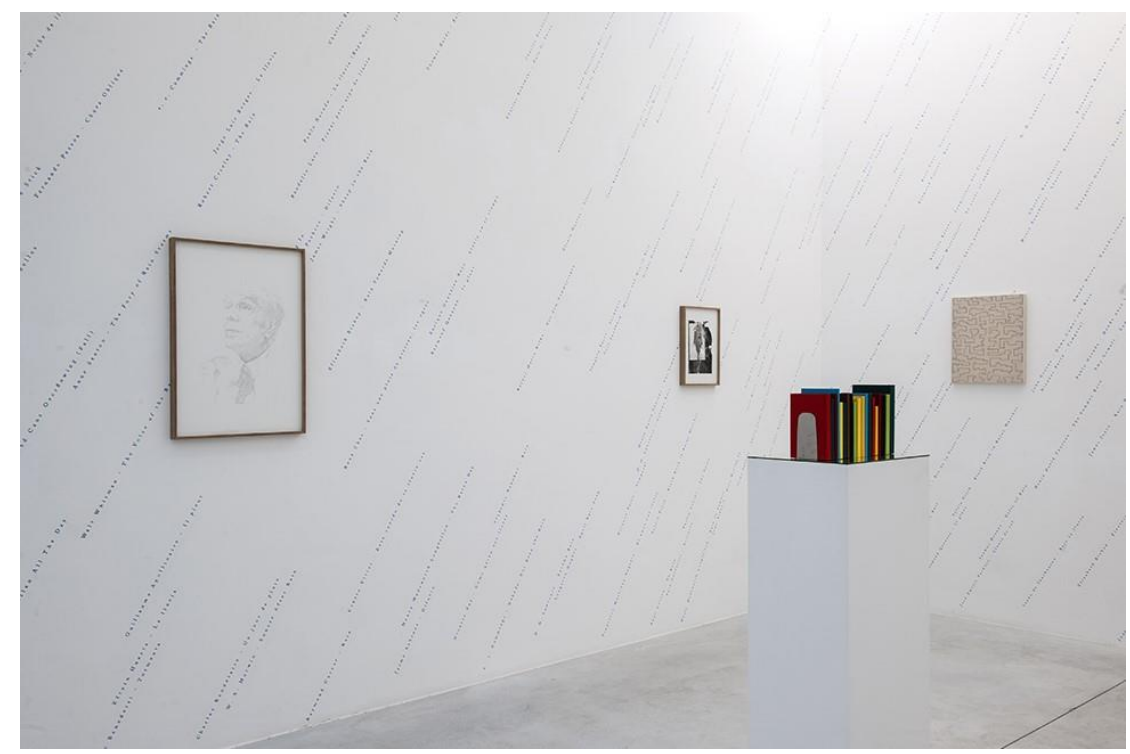

Fig. 7. Jorge Méndez Blake, All the Borges' Books. This installation was originally presented at the section Frame of New York's Frieze, May 3-7 20I2, in Roosevelt Island N.Y. Reproduced with the kind permission of Jorge Méndez Blake.

Eugenio Tisselli (born in 1972), who lives in Spain, is currently one of the main and most well-known Mexican artists to work in digital art. ${ }^{32} \mathrm{~A}$ pioneer in this field, he has been working for a long time with natural and artificial languages and showing a deep political and social engagement in his research work as well as a questioning attitude and a critical awareness towards technology and machines. An example of his most recent work is La tirania del código [Tyrany of the Code] (2015) (see Fig. 8), a I7-minute video 33 that implicitly addresses the continuities and discontinuities between contemporary digital creative movements and the Russian avant-garde. This

\footnotetext{
${ }^{32} \mathrm{His}$ work can be seen at www.motorhueso.net/ (accessed 25 March 2018).

${ }_{33}$ Eugenio Tisselli, La tiranía del código, 20I5, https://vimeo.com/213II2034 (accessed 24 February 20I8).
} 
piece uses different video samples that the artist captured of streets and buildings in Mexico City, which he manipulated by using MIDIPoet, a software tool designed by him, which allows the manipulation of text and image on the computer screen. A 43verse poem (in paper) complements the piece. Conceptually, as the artist explains, "MIDIPoet is based on the notion of field of events, which consists in a series of potential behaviors of the visual elements on the screen, which occur or not, according to internal conditions or external manipulations." ${ }^{34}$ By employing this tool, the piece explores the glitch as a casual event that can contribute to the creation of an alternative psychedelic scenario.

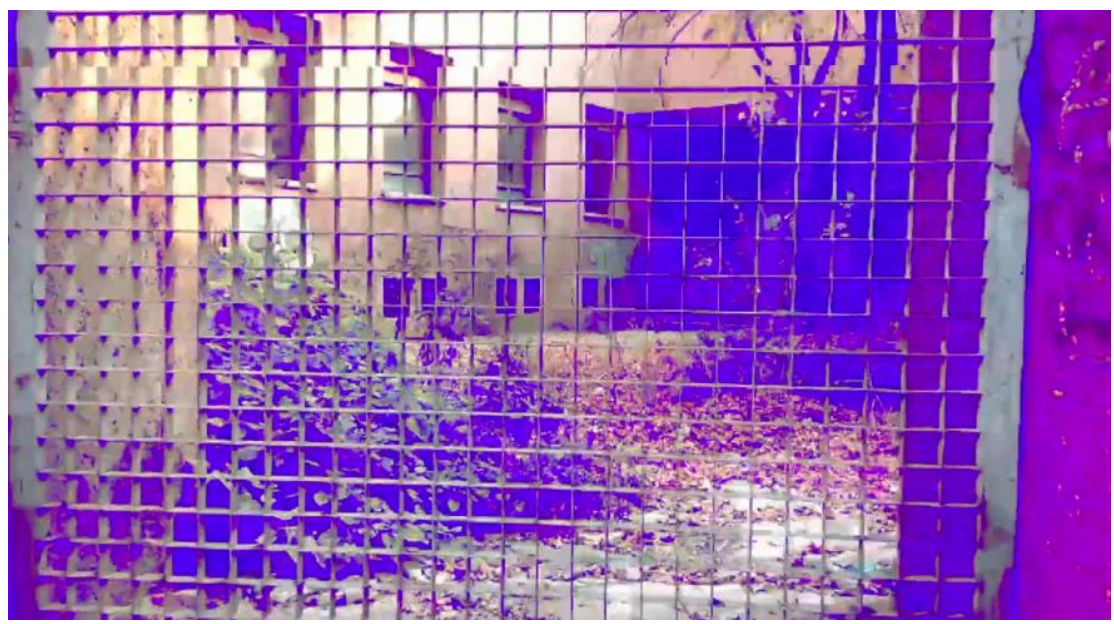

Fig. 8. Still from the video La tiranía del código, Eugenio Tisselli, 2015, video, 17:06 min., https://vimeo.com/2I3I2034. Hyperlink included with the kind permession of Eugenio Tisselli.

In another digital piece called $E l 27$ [The 27th] (2015) (see Fig. 9),35 which can be found in the third volume of electronic literature made by the Electronic Literature Organization (which, by the way, includes five Mexican works), Tisselli created a piece based on algorithmic literature in which each time the stock exchange market in New York closes with a positive percentage variation, a line of text is automatically translated into English. The text is a fragment of the 27 th article of the Mexican Constitution, which establishes that land and water within the limits of the

34 Our translation from the Spanish version available here: http://motorhueso.net/midipoet/ (accessed 24 February 2018).

35 Eugenio Tisselli, "El 27/The 27th," Electronic Literature Collection, vol.3, 2016, http://collection.eliterature.org/3/work.html? work=the-27th (accessed I2 June 20I7). 
national borders are originally part of the nation, but their ownership can be transmitted to individuals through the right of private property. The translated text always appears in red letters. Hereby, the piece involves programming, textual conditions, and social repercussions as a strongly critical statement. For different museum exhibitions, this piece has been presented as a material text, printed in a large format (plotter), which gives the impression of a large "red" carpet, with only a few textual elements left in Spanish. It is partially fixed on the wall and continues over the floor for some meters, expecting the visitor to read the text while physically and symbolically stepping on it. The whole project in its material treatment and disposition metaphorically speaks of many contemporary and political circumstances that are a consequence of the relationship between Mexico and the United States as neighbour countries. Again, as with the artists mentioned so far, in this piece Tisselli is consciously exploring and working with the implications of textuality as an ideological-discursive form, and the outreach of linguistic translation, only he refers to the complex networking-system that determines the act of this conversion.

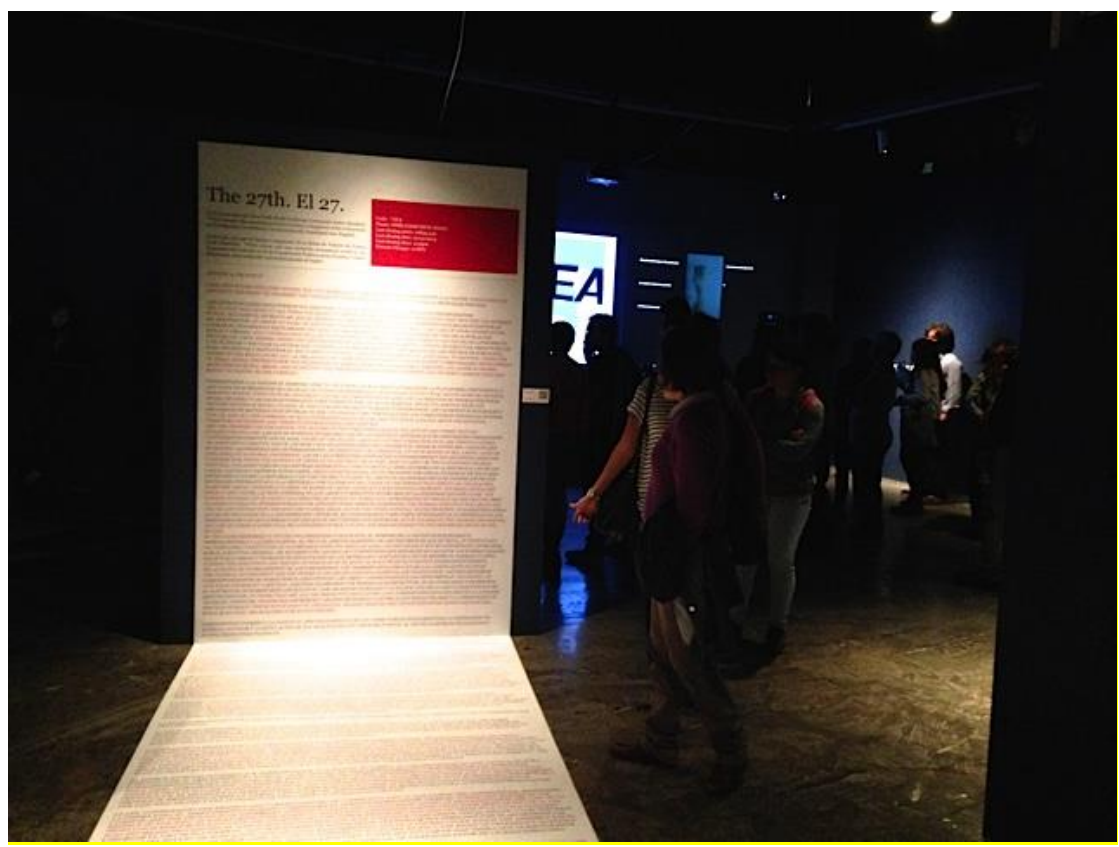

Fig. 9. Eugenio Tisselli, El $27 \|$ The 27th, 2013, image of the exhibition Literatura electrónica: política y cuerpo en el presente digital [Electronic Literature: the Politics and the Body in the Digital Present], part of the project Plataformas de la imaginación [Platforms of the imagination], Centro Cultural Tlatelolco, Mexico City, novembre 20I5-january 2016. Photo by Susana González Aktories. Reproduced with the kind permission of Eugenio Tisselli. 
As an artist who is extremely conscious of media, particularly in recognizing and underlining the ecological as well as social damage created by our contemporary use of electronic devices, not only because of their programmed obsolescence, but also due to the ways in which many of its components are extracted from nature, in 2oII Tisselli published a text where he explains why he temporarily decided not to continue writing e-literature as he had done for more than ten years. ${ }^{36}$ Instead, he started using technology and these types of media to help disadvantaged communities to improve their way of living. For example, he has worked with rural communities in Tanzania, Oaxaca, and other places helping them to communicate their ancient agricultural knowledge through mobile devices and allowing them to track and compare the results of each of their strategies in order to improve decisions over a longer time span.

Through devices and dynamics very different from the ones applied by the previous generation of artists, but somehow moved by similar social and aesthetic principles (mainly if we recall Ehrenberg's work), Tisselli shows that art and literature are discourses and practices that are extremely linked to a social and political state and that need to be more consciously analyzed. Intermedial means give him the possibility to stress this point throughout both his artistic work and his theoretical-critical writing. For instance, in “¿Por qué escriben las máquinas que escriben? [Why Do Machines That Write Write?],” one of his reflections on poetry 37 that dealt with contemporary tendencies in poetry, Tisselli clearly shows that he represents a generation of artists that grew up in direct coexistence with electronic devices and digital culture, a generation that uses videogames and computers, and who "see" their music through musical videos.

Rafael Lozano Hemmer (born in 1967), ${ }^{38}$ the last Mexican artist we want to refer to in this short overview, also has a very interesting and original proposal that relates text, image, and sound, but in an entirely different way than Tisselli, using technology to make our condition of subjects-objects evident. Lozano Hemmer works with, among other devices, cameras and other electronic elements used for visual control, locating them in galleries and museums with the purpose of exposing

\footnotetext{
${ }^{36}$ Eugenio Tisselli, “¿Por qué he dejado de crear e-literatura?,” 20I5; available in English: "Why Have I Stopped Creating E-Lit," Netartery, 25 November 20II, http://netartery.vispo.com/?p=I2II (accessed 24 February 20I8).

37 "¿Por qué escriben las máquinas que escriben? [Why Do Machines That Write Write?],” El Jolgorio, no. 66, 2013, p. 46-48, https://issuu.com/eljolgorio/docs/el_jolgorio_cultural_66/5 (accessed 24 February 2018).

${ }^{38}$ Lozano Hemmer has lived for many years in Montreal. His work can be seen at http://www.lozano-hemmer.com/projects.php (accessed 24 February 2018).
} 
our image in a Foucauldian way. This is the case of Zoom Pavilion, made in 2015, an interactive installation that consists of an immersive projection on three walls, fed by twelve computerized surveillance systems trained on the public. The piece uses face recognition algorithms to detect the presence of participants and record their spatial relationship within the exhibition space. Independent robotic cameras zoom in to amplify the images of the public with up to $35 \mathrm{x}$ magnification. Here the spectators become part of the piece, looking at themselves, almost as if deliberately made to "read" their own image. Lozano Hemmer uses eye sensor machines to make the audience be seen by his pieces.

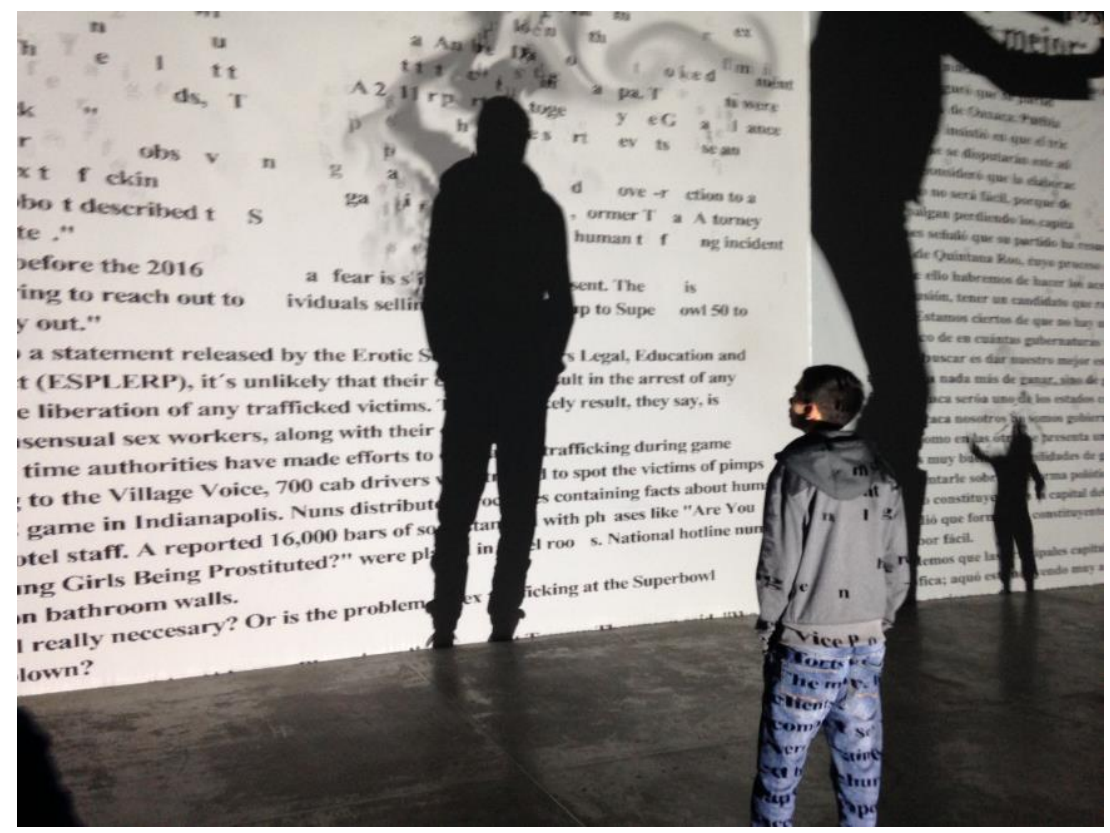

Fig. 1o. Rafael Lozano Hemmer, Airborne, projections, surveillance cameras, computers, custom-made software, installation view, image of the exhibit Psendomatismos, Museo Universitario de Arte Contemporáneo, October 2015-April 2016. Photo by Susana González Aktories.

In Bilateral Time Slicer (2016), a piece prepared for an exhibit that used a biometric tracking system, he programmed it to find the axis of symmetry of the visitors entering that room and splits a live camera image into two slices. With each new participant, time slices are recorded and pushed aside. When no one is viewing the work, the slices close and rejoin creating a procession of past recordings. Here, by working with time itself as the topic and material of the piece and using technology, 
Lozano Hemmer is questioning and renewing our temporal conception. Call on Water, from the same year, is a fountain that writes words in mid-air with plumes of cold vapor that rise from a water basin. Dozens of poems by Mexican writer Octavio Paz are presented that describe readable air, the moment when the written word is spoken and becomes the atmosphere itself. The poems' content becomes tangible briefly, almost breathable, then disappears in turbulence.

As can be seen from these few examples, the "technological turn" in art production has been fundamental to intermediality since it has given many more layers to the creation and understanding of different media and languages in interaction. And, again, the artists who are currently working with technology are also experimenting and showing a spirit of criticism towards media themselves very much in tune with the intermedial intentions displayed by the artists of the former generation.

\section{FINAL THOUGHTS}

Where is intermediality situated in Mexico, if we take as a departing point scenarios such as the ones broadly sketched here? To a great extent, it still lies in a territory where it is constantly reshaping and reaffirming itself. As such, intermediality continues to benefit from being a plural endeavour in which the apparently ambiguous, the pluridiscoursive and polysemic seem to be-and probably should continue to be-at its very centre. Is this perhaps what characterizes intermediality? In any case, we believe that these types of discourses may help critics identify more convincingly what intermediality can be about and how media have helped to shape and transform this vision, where the "intermedial turn," rooted in a range of language systems, situations, and contexts, is in the process of becoming.

In this article we underlined the work of several artists who have become better known by both the general public and critics and scholars, but the list of those who are exploring intermedial practices is long and keeps growing. An important consideration is that most of these artists have also been writing and theorizing about their ideas on art. In this way they help us rethink and reshape media interaction as a way of generating a productive friction of different languages and materials put in contact. We can even say that some of these artists have been almost as influential in their role as critics as they have been as creators. Carrión and Ehrenberg's work, for instance, cannot be thoroughly understood if we do not look at their ideas on art, art production, artistic circuits, and markets of exchange. However, neither can we understand other artists' works of that time-even if they are not rooted in 
intermediality or in, so to speak, experimental practices-without considering their views on Mexican and international art. The same is true for artists of the new generation, such as Amorales or Méndez Blake, who are also making a statement about the polysemic possibilities of working on mixed media and offering reflections both through their artistic work and their comments on contemporary art culture. On the other hand, some of these new artists have become very influential in Internet forums such as Twitter, blogs, or through their personal websites where they express their theoretical-poetical-meta-artistic standpoints. For example, in Tisselli's case, even if he has lived abroad for many years, mainly in Barcelona, his presence is clearly acknowledged and followed by his fellow artists and critics in Mexico. In a sense, this gives a different perspective on this artist's work than the perspectives on the work of Carrión and Ehrenberg who also lived abroad: Carrión was, until very recently, ignored within the artistic and literary circles in Mexico and Ehrenberg harnessed his marginal yet resilient fighting spirit as an opportunity to address new social groups and in ways that took distance from the by then conventional formats of cultural and academic discourses in Mexico. The Mexican art circuit is now therefore being deepened and enlarged without exclusively circumscribing to Mexico. Today we can confirm that both generations of artists are well accepted by international and national audiences. This is also a proof that their aesthetic and philosophical concerns are not regionally bound, but deal with much broader ideas on art and art production.

Even from this partial overview it is evident that there has been an "intermedial turn" in the artistic production and in the way artists and audiences conceive contemporary art-including literature-in Mexico. Mexican artists active during the second half of the twentieth century until today do not necessarily define themselves as bound by disciplines and they contribute not only to an understanding of the development of the artistic scene but also, and most importantly, to rethinking intermediality with regard to other areas, such as sound art, comparative literature and literary theory, and media-specific orientations such as media communication, media technology, electronic media, philosophy of technology, and media archeology. Approaching media as cultural contexts and circumstances, media as an aesthetic terrain linked to different means and languages, and media as a material element, they often reveal in illuminating ways those complex relations, fusions, interactions, transpositions, and combinations as the ones derived from intermedial mappings like the famous chart proposed by Dick Higgins. ${ }^{39}$ By now they have even

39 Dick Higgins, Intermedia Chart, 1995. 
helped to fill some of the gaps he had deliberately left open in his chart (indicated with just a question mark), and have even added new ones as a result of a series of remediation processes that he himself could not have foreseen twenty years back.

Media, as used and critically conceived by contemporary artists in their work and poetics, are no other than those mixed media that W. J. T. Mitchell ${ }^{\circ}$ brightly referred to, where the hierarchy of one medium over the other, the inquiry into the diachronic and historical ideas of evolution of each discipline, or even the derivation of one artistic form from another do not seem to be an issue. Rather, what becomes relevant are the effects caused by this hybridity - in its very essence of "inter-being"and the artistic concerns this raises in conceptual, aesthetic, social and even political terms.

Moreover, this brief retrospective track we have intended here shows that these artists have become more and more conscious of their choices. They are also interested in showing as part of their work and conception what "media" are made of-their structures, codes, and languages-in an extremely complex structure of layers that is often presented in a critical as well as playful, explorative, schematic, updated, and therefore attractive way.

We have finally aimed to show some of the paths that have led contemporary artists to become influenced by earlier artistic uses of word-sound-image elements as well as other intermedial components and techniques. Due to the work of these artists (as well as many others that still need to be carefully revisited), their gradual assimilation within the Mexican art scene and their theoretical contribution to academia in intermedial and interdisciplinary matters, they have opened up even more institutionalized ways of recognition for this type of work, such as through grants and prizes that include special categories for mixed media proposals. This has led to a greater familiarization with these practices as they may be encountered in museums, galleries, books, or by other means of cultural communication. Artistic intermediality, as we have come to know it, seems to continue being one step ahead of literary or artistic analyses. But is not this its truest nature, by which it has been raising our growing academic awareness? Even if we have focused here on the Mexican artistic scene, we believe that similar observations can be made about intermediality's condition and evolution in many other cultural contexts.

${ }^{40}$ W. J .T. Mitchell, “There Are No Visual Media,” Journal of Visual Culture, vol. 4, no. 2, 2005 , p. 257-266. 


\title{
Thinking Intermediality in Mexico through Artistic Input
}

\author{
SUSANA GONZÁlEZ AKTORIES \\ MARIA ANDREA GIOVINE YÁÑEZ \\ National AUTONOMOUS UnIVERSiTy OF MEXICO
}

\section{ABSTRACT}

By highlighting certain paradigmatic moments and protagonists in Mexican contemporary art that reach back to the second half of the last century and continue until today, this article aims to show the undeniable "intermedial turn" that has become foundational not only for understanding current artistic movements in Mexico, but also for Mexican academia, where critics have only gradually started to recognize how an intermedial perspective may help them understand and analyze artistic proposals that can no longer be discussed from a strictly mono-disciplinary standpoint. Contributions by emblematic artists such as Mathias Goeritz, Felipe Ehrenberg, and Ulises Carrión, who have used words, images, and sound elements to broaden artistic boundaries in new and surprising ways, have been echoed and problematized in novel forms by contemporary visual artists such as Carlos Amorales and Jorge Méndez Blake as well as media artists Rafael Lozano Hemmer and Eugenio Tisselli, some of whom are also valuable interlocutors in matters of intermediality as they continue to critically theorize and sharply reflect on these types of practices.

\section{RÉSUMÉ}

Cet article présente quelques moments paradigmatiques de l'art mexicain contemporain de la seconde moitié du $20^{\mathrm{e}}$ siècle jusqu'à aujourd'hui. Il a pour but de montrer l'indéniable « virage intermédial » qui s’est opéré au cours de cette période et qui permet de comprendre certains mouvements artistiques mexicains actuels ainsi que la réflexion qui s'est parallèlement élaborée dans le milieu universitaire. Ce n'est que depuis très récemment que les chercheurs reconnaissent qu'une approche intermédiale peut contribuer à la compréhension et à l'analyse de propositions artistiques qui ne peuvent plus uniquement être discutées d'un point de vue monodisciplinaire. Les contributions des artistes emblématiques Mathias Goeritz, Felipe Ehrenberg et Ulises Carrión, qui ont employé des mots, des images et des éléments sonores pour élargir les frontières artistiques, ont par exemple trouvé un écho chez des artistes visuels comme Carlos Amorales et Jorge Méndez Blake, ainsi que chez des artistes pratiquant les arts médiatiques comme Rafael Lozano Hemmer et Eugenio Tisselli. Ces artistes, puisqu'ils adoptent une posture théorique par 
rapport à leur pratique, constituent des interlocuteurs pertinents à l'égard de la réflexion sur l'intermédialité.

\section{NOTE BIOGRAPHIQUE}

SUSANA GONZÁlEz AKTORIES is a full time professor and researcher in Comparative Literature at the National Autonomous University of Mexico (UNAM). Her main fields of research are semiotics and intermediality, with a special focus on comparing literature and music. In recent years she has co-edited volumes such as Reflexiones sobre semiología musical or Entre artes/entre actos: ecfrasis e intermedialidad. She is founder and member of the Laboratory of Extended Literature and Other Materialities (lleom.net). a full-time professor and researcher in Comparative Literature at the National Autonomous University of Mexico. Her main fields of research are semiotics and intermediality, with a special focus on comparing literature and music. In recent years she has co-edited the volumes Reflexiones sobre semiología musical and Entre artes/entre actos: ecfrasis e intermedialidad. She is founder and member of the Laboratory of Extended Literature and Other Materialities (lleom.net).

MARÍA ANDREA GIOVINE YáÑ̃z is a full-time professor and researcher at the Institute of Bibliographical Research (National Autonomous University of Mexico). Her main fields of research are visual poetics and the relationships between literature and the visual arts. Since 2013, she has been a member of the Laboratory of Extended Literature and Other Materialities (lleom.net). 